Published in final edited form as:

Economica. 2016 January ; 83(329): 1-30. doi:10.1111/ecca.12168.

\title{
Education as Liberation?
}

\author{
Willa Friedman ${ }^{\dagger}$, Michael Kremer ${ }^{\ddagger}$, Edward Miguel ${ }^{\dagger \dagger}$, and Rebecca Thornton $¥ \ddagger$ \\ tUniversity of Houston \\ ‡Harvard University and NBER \\ t+University of California, Berkeley and NBER \\ ¥ University of Illinois at Urbana-Champaign
}

\begin{abstract}
This paper studies the political and social impacts of increased education by utilizing a randomized girls' merit scholarship programme in Kenya that raised test scores and secondary schooling. Consistent with the view that education empowers the disadvantaged to challenge authority, we find that the programme reduced the acceptance of domestic violence and political authority. Young women in programme schools also increased their objective political knowledge. We find that this rejection of the status quo did not translate into greater perceived political efficacy, community participation or voting intentions. Instead, there is suggestive evidence that the perceived legitimacy of political violence increased.
\end{abstract}

\section{Introduction}

Education policies have often been motivated by beliefs about education's political impacts. Several US states historically restricted the education of slaves for fear that it would encourage revolt (Woodson 1915), and Belgian colonial authorities in Africa enacted similarly restrictive education policies (Hochschild 1999). Post-independence authorities in Africa expanded education with a goal of promoting national identity and integration (Nyerere 1973), as it had earlier been used in Europe (Weber 1976). The view that expanding girls' educational access is a key to speeding the rise of female politicians and women's empowerment was a factor in the adoption of the third United Nations Millennium Development Goal (Herz and Sperling 2004; Levine et al. 2008). Girls' scholarship programmes in particular have been used to move towards this goal. Officials in Bangladesh cite women's empowerment as a main objective of their scholarship programme (Rynor and Wesson 2006), and there are also large programmes in other regions, including in Egypt and Cambodia (Iqbal and Riad 2004; Filmer and Schady 2008).

This paper exploits a randomized merit scholarship competition for adolescent girls in Kenyan schools to identify the political and social impacts of the programme and of education more generally. Other research has demonstrated that the incentives created by the 
programme led to higher academic test scores (Kremer et al. 2009). In this paper we analyse data from a follow-up survey collected four to five years after the scholarship competition, when the young women were between 17 and 21 years of age.

Less developed regions have experienced massive increases in both education and democracy over the past half century, as illustrated by Kenya (see Figure A1, panel A, in the online Appendix), and there has been extensive debate on how these trends might be interrelated.

Modernization theorists argue that education weakens traditional ascriptive attachments based on gender, hereditary position, ethnicity and religion, in favour of merit (Levy 1966). Lipset (1959) famously argues that education promotes democratization. ${ }^{1}$

Another view argues that education serves as a tool of cultural indoctrination and social control, instilling obedience to authority (Lott 1999; Kremer and Sarychev 2008). Bowles and Gintis (1976) claim that US education reinforces the class structure by training citizens to obey authority within the hierarchical modern corporation. Gramsci (1971) and other social theorists (Freire 1972) advance related points on its central role in bolstering the cultural hegemony of ruling elites, while simultaneously emphasizing that alternative forms of education could be instruments for social change favouring the 'liberation' of the oppressed.

A third school of thought views education as promoting individual autonomy and empowerment. In observational studies, education is correlated with: greater individual political knowledge (Almond and Verba 1963; Verba and Nie 1972; Hanushek 2002; Bratton et al. 2005; Mattes and Bratton 2007); interest in obtaining political information (Dee 2004); greater dissatisfaction with existing institutions; and more support for women's rights (Weakliem 2002). ${ }^{2}$ While correlations have been documented between education and political interest, participation and voting among individuals in wealthy countries (Verba and Nie 1972; Wolfinger and Rosenstone 1980; Weakliem 2002; Dee 2004; Milligan et al. 2004; Glaeser et al. 2007), Galston (2001) notes that historical increases in US education have not been followed by higher aggregate voter turnout. Moreover, the evidence in poor countries is mixed. While Logan and Bratton (2006) find a positive correlation between education and political participation in 15 African countries, Blaydes (2006) finds a negative association between voting and education in Egypt, and argues that this is mainly due to vote-buying. Some argue that education is politically empowering for women in particular. Basu and King (2002) find that educated Bangladeshi women are more likely to participate in political meetings. ${ }^{3}$

\footnotetext{
${ }^{1}$ Dahl (1973) similarly asserts that education increases the potential for successful democracy. See also Acemoglu et al. (2005, 2008), Barro and Lee (2001), Boix and Stokes (2003), Boix (2009), Epstein et al. (2006), Huntington (1991), Papaioannou and Siourounis (2008) and Przeworski and Limongi (1997), among others.

${ }^{2}$ Lochner (2011) and Oreopoulos and Salvanes (2011) survey this literature. One way to understand the empowerment view of education is that schooling boosts individual capabilities, improving both cognitive and non-cognitive skills, along the lines of Heckman (2007).

${ }_{3}$ Political empowerment need not be benign; see Davies (1974), Miller et al. (1977) and Krueger and Maleckova (2003). Duflo (2012) surveys the impacts of female education.
} 
A major difficulty in estimating the impact of education on individual attitudes and behaviour is the possibility of reverse causality. For example, if those who are less willing to accept authority are less likely to stay in school, then cross-sectional correlations between education and acceptance of authority will confound the causal impact of education on willingness to accept authority with the impact of acceptance of authority on education. Most existing studies estimate correlations between education, attitudes and behaviours in ways that are potentially vulnerable to this critique. ${ }^{4}$ One strategy for addressing this problem, which we adopt in this paper, is to exploit randomized variation in education to separately measure the impact of such education on acceptance of authority. The use of experimental designs to study political economy questions is growing. ${ }^{5}$ A limitation of this micro-experimental approach is that we measure the impact of education induced by a particular policy in a single population. Yet insofar as similar policies oriented at boosting girls' education have been widely advocated and implemented in low-income countries, creating evidence on the impact of these programmes is itself an important objective, and can complement existing non-experimental analyses.

This paper takes advantage of the experimental Girls' Scholarship Programme (GSP) in Kenyan primary schools, which persistently boosted academic test scores and increased secondary school enrolment among girls from treatment schools. ${ }^{6} \mathrm{We}$ find that exposure to the programme reduces young women's acceptance of the right of men to beat their wives and children, and there is evidence that it reduces the likelihood that parents are involved in choosing their daughters' spouses. These findings are broadly consistent with both modernization theory and the view that education promotes a desire for autonomy and empowerment, but are harder to reconcile with the claim that education tends to reinforce existing patterns of authority.

There is no evidence that the human capital created by the GSP leads to more prodemocratic or secular attitudes, or weakened ethnic identification; these results are not consistent with a modernization perspective. In fact, we provide suggestive evidence that ethnic identity grows stronger among programme beneficiaries, despite the Kenyan school curriculum's stated aim of promoting feelings of national unity.

Consistent with the view that education leads to a greater desire for autonomy, GSP participants are more likely to read newspapers and better able to identify a favourite news source. They also possess more objective knowledge about politics, and express less satisfaction with Kenya's democracy and current economic conditions. However, these impacts do not translate into greater perceived political efficacy or involvement as measured by voting intentions or participation in community groups. Instead, there is some suggestive evidence that the young women express greater willingness to accept the legitimacy of violence in politics. The increased acceptance of violence may not be surprising given: the

\footnotetext{
${ }^{4}$ There are exceptions to this critique, including Milligan et al. (2004), Dee (2004) and Sondheimer and Green (2010), who exploit natural experiments in US data, and Smith et al. (2009), Gulesci and Meyersson (2012), and Mocan and Cannonier (2012), who leverage policy changes in international settings. Gottlieb (2015), Larreguy and Marshall (2015), Croke et al. (2015) and Wantchekon et al. (2015) exploit experimental or historical variation to study related issues in other African settings.

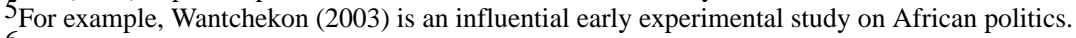

${ }^{6}$ In another study, Jakiela et al. (2014) exploit the random assignment of the GSP to estimate the impact of education on respect for earned property rights using lab experiment data.
} 
limited scope for our study participants to effect change in Kenya's fledgling democracy; their greater dissatisfaction with, but no greater participation (or belief) in democracy; and the finding that ethnic identification does not diminish with education. It also resonates with the fact that violence has been a central feature of political change in Kenya, from the anticolonial Mau Mau uprising to the contested 2007 election.

Returning to the perspectives outlined above, our findings appear equally inconsistent with the view that education promotes 'modern' attitudes, and with the claim that education instils acceptance of existing authorities. Rather, they suggest that education promotes a desire for personal autonomy among the marginalized young rural women that we study, but that this desire is not necessarily expressed through democratic means. We see evidence of greater political knowledge and raised expectations, but not of actual political involvement, and perhaps as a result, we document greater frustration with the status quo and acceptance of political violence. This suggests that while young women may be less willing to accept violence directed against them by others, this does not stem from an abstract rejection of violence, and that indeed they may be more willing to accept political violence as necessary in some circumstances.

Methodologically, it is useful to know whether a non-experimental analysis would yield similar results. We find large differences between experimental IV estimates derived from the randomized design and non-experimental correlations, suggesting that non-experimental correlations cannot be interpreted as causal impacts of education. Under a simple model of bi-directional causality, our findings can be interpreted as suggesting that those who are less willing to accept authority are likely to accumulate considerably less human capital in Kenya.

To further get at the channels of impact, and in particular at whether these effects are directly due to receiving additional education through the merit-based scholarship competition, or to the money or prestige garnered by winning a scholarship itself, we examine a subset of girls who had very low ex ante odds of winning the scholarship based on their baseline test scores. As shown in Kremer et al. (2009), these girls also experience test score gains through the programme. The main impacts on social and political variables also hold in this subsample, supporting the view that the human capital channel is important.

As with all micro-studies conducted in a given context-here, among young Kenyan women - caution is requiring in generalizing the results to other populations, most notably for males and older adults, for whom we lack data. Our results can be taken as relevant for rural Kenyan females at the margin of transitioning from primary schools-which are very much part of the fabric of village life - to secondary schools, which offer a much broader perspective of Kenya and the world. To what extent should we expect our results to generalize? While it is impossible to know for certain without further work, a natural conjecture is that the education of disadvantaged social groups—such as the rural women from politically marginalized ethnic groups in our sample-will induce greater awareness of politics, increase the desire for autonomy, and reduce tendencies to simply accept their powerlessness as a natural, immutable fact about the world. In our context, there is some indication that this may translate into increased ethnic attachment and greater acceptance of 
political violence. Yet it is plausible that in other contexts where there is greater scope for meaningful engagement in democratic politics, the heightened political consciousness and reduced acceptance of authority might instead lead to greater civic involvement, potentially contributing to a more vibrant democracy.

\section{Background}

\section{The study setting}

The Kenyan girls in the setting that we study are socially marginalized and politically disempowered. They are female and young in a society where older males hold authority, residents of a rural backwater, and overwhelmingly from the quite politically weak Luhya and Teso ethnic groups. Women are also disadvantaged in Kenyan society more broadly. Female participation in parliament is low, at just $10 \%$ (Gathigah 2010). Spousal violence is also widespread, with $75 \%$ of women claiming abuse in recent reports (FIDA 2008). In the household realm, Kenyan girls are generally subject to their parents'-and in particular their father's-authority until they leave the household, and then are often subject to their husband's authority. Traditionally, parents played a central role in selecting husbands for their daughters and received bridewealth from the groom in the form of livestock (Were 1986). However, while this system remains normative in some sense, in practice it has largely broken down in favour of a system in which young people 'elope' with partners of their choice, and bridewealth is either never paid or is paid later (if the groom accumulates sufficient resources). In rural areas, unmarried women, unlike men, are not permitted to build their own separate house on a family compound, and are thus more directly subject to parental authority. Many young women therefore marry at an early age, at least in part to escape parental control.

Our study area is Busia, a district in western Kenya with below-average income levels. ${ }^{7}$ Ethnic Luhyas comprise roughly $80 \%$ of the sample, with some Luos and Tesos (Table 1). Although Luhyas are among Kenya's most numerous groups, Luhya politicians have been unsuccessful in the competition for the presidency. Kenya's first president was Jomo Kenyatta, from the Kikuyu ethnic group, the second (Daniel arap Moi) was a Kalenjin, and the third (Mwai Kibaki) was a Kikuyu. There is a widespread perception in Busia that these presidents' ethnic groups wielded disproportionate power during their rule, to the detriment of western Kenya.

Like many African countries, Kenya became a de facto single-party state shortly after independence in the 1960s, and underwent democratic reforms in the early 1990s at the end of the Cold War. The Kenyan African National Union retained power until 2002, when a multi-ethnic coalition led by Mwai Kibaki defeated Moi's handpicked candidate. When Kibaki in 2005 proposed a new constitution seen as preserving a strong 'imperial' presidency and favouring Kikuyu elites, voters overwhelmingly rejected it, including voters in our study area. Thus during 2005-7 when our survey data collection took place, Kenya

${ }^{7} 62 \%$ of Busia households live in poverty compared to $41 \%$ nationally. As Kenyan per capita income is somewhat higher than the Sub-Saharan African average (if South Africa is excluded), Busia's relative poverty arguably makes it more representative of rural Africa as a whole. 
had an imperfect but reasonably competitive multi-party democracy. This is reflected in its Freedom House score of 3 during the period (scale of 1 to 7, with 1 being most democratic; see online Appendix Figure A1, panel B).

Yet the fragility of this democracy was starkly demonstrated in late 2007 and early 2008. The incumbent was widely seen as having stolen the presidential election (Gibson and Long 2009). Individuals living in the study area overwhelmingly supported the challenger Raila Odinga. Protests against the incumbent's declaration of victory became violent, ethnic clashes broke out across the country, and some observers believed that Kenya was on the verge of civil war. Due to a combination of internal and external pressure, the incumbent eventually acceded to a power-sharing agreement with the challenger.

Since independence from Britain in 1963, Kenya has experienced massive increases in education, with adult literacy rising from just 32\% in 1970 to 87\% today (UNDP 1993, 2010). Although there are huge gender disparities in other areas of Kenyan society, census data indicate that girls' enrolment has increased at a faster rate than boys' at lower levels of education (online Appendix Figure A1, panel A), and there is now gender parity in primary school enrolment (UNDP 2009). Kenya's increase in education is dramatic, with average schooling attainment rising to 5.9 years by 2000 (Barro and Lee 2001), but many other countries have also seen similar gains. To illustrate, in 1960 the average working-age person in low-income countries had 1.8 years of education, while by 2000 they had over five (Barro and Lee 2001).

As background, the Kenyan school system is quite authoritarian. Corporal punishment is commonplace (Human Rights Watch 1999), and challenges to teacher authority are not tolerated. Student prefects help teachers to maintain classroom control, students wear uniforms, learning is by rote, and creativity and critical thinking in the classroom are not highly prized. It is unlikely that Kenyan schools would be viewed as instruments of liberation in the sense of Freire (1972).

Despite this emphasis on discipline and rote learning, the Kenyan school curriculum officially attempts to promote democratic values, and a national Kenyan - as opposed to ethnic -identity. For example, two chapters of History and Government, a first-year (Form 1) high school text approved by the Ministry of Education, are entitled 'Citizenship' and 'National integration'. ${ }^{8}$ This text states: 'Citizens have the responsibility of participating in the democratic process through which our leaders are elected.' Under 'Elements of good citizenship' it lists nationalism, explaining that: 'a nationalist works for one's country and devotes oneself to serving the nation and the unity of his/her nation. Thus a Kenyan nationalist is devoted to Kenya and seeks to unite fellow countrymen above interests of race, tribe, religion or parochialism.'

Primary school in Kenya runs up to grade 8, after which students take a national exam, and those with sufficiently high scores continue on to secondary school. Historically, attending

\footnotetext{
${ }^{8}$ We focus on Form 1 since the GSP increased secondary school participation, as shown below.
} 
secondary school has been associated with higher social status, since secondary schools are selective and much more expensive than primary school, and many are boarding institutions.

\section{The Girls' Scholarship Programme}

In March 2001, ICS, a Dutch non-profit organization, introduced a merit scholarship competition in 34 primary schools in the western Kenya district of Busia, with 35 other schools serving as the control group. This Girls' Scholarship Programme (GSP) provided an award to grade 6 girls in treatment schools whose performance on the government's standardized end-of-year exam placed them in the top 15\% (among all girls in the treatment schools). The award included a grant of $500 \mathrm{KSh}$ (or roughly US\$6.40 at the time) paid to the girl's school to cover school fees, and a cash grant of $1000 \mathrm{KSh}$ (or US \$12.80) paid to the girl's family to pay for other school expenses, in each of the two years following the competition, covering the last two years of primary school. Thus the total award for winners was valued at nearly US $\$ 38$ over two years, an amount comparable to the large-scale girls' scholarship programmes in other less developed countries (including Bangladesh, Cambodia and Egypt) mentioned above. For comparison, Kenya's annual per capita income was roughly US $\$ 400$ in 2001 . The awards were presented at local community assemblies. ${ }^{9}$

The randomization into treatment and control schools was carried out using a computer random number generator, after first stratifying by administrative division and participation in a previous intervention (that distributed flip-charts as classroom learning aids) also carried out by ICS. All 34 schools invited to participate chose to take part in the project. GSP treatment and control schools in Busia are similar on baseline characteristics (Table 1, panel A), indicating that the randomization worked in generating similar groups; the first column in Table 1 presents the mean (and standard deviation) in the control group, and the second column presents the coefficient estimate on the treatment indictor variable. The organization did not conduct other activities at these schools during the study, so we can attribute impacts to the GSP.

There was a parallel evaluation in the neighbouring Teso district that is discussed in Kremer et al. (2009). However, since the Teso sample was far smaller, had considerable attrition during the original study, and did not experience an obvious increase in human capital as a result of the programme, the follow-up surveys were conducted only in Busia district and we thus focus on the Busia programme in this paper.

The Kenyan school year runs on the calendar year, from January to December (online Appendix Figure A2). The programme was publicly announced early in 2001. The competition was carried out a second time in treatment schools in 2002 among students in grade 6 in that year (and eligibility was restricted to those girls who had been initially enrolled in grade 5 in the same schools in 2001, to eliminate the possibility of selective transfers into treatment schools). There were thus two cohorts in the programme, those in grade 6 in 2001 and those in grade 6 in 2002.

\footnotetext{
${ }^{9}$ Although primary school fees were eliminated in 2003, certain expenses remained, and Evans et al. (2010) find that these remained an important barrier to participation.
} 
The average 2001-2 treatment effect of GSP incentives on test scores in Busia district was nearly 0.30 standard deviations, and the 2001-2 estimated effect in our follow-up subsample was 0.34 standard deviations (Table 1, panel B; Kremer et al. 2009). ${ }^{10}$ These are considered large gains in the education literature (McEwan 2014). As is standard, test scores are normalized such that the control group distribution has a mean of zero and a standard deviation of one. ${ }^{11}$ Importantly, the programme generated higher test scores in treatment schools both for those who were most likely to benefit from the scholarship—girls with high baseline scores-but also for those who were unlikely to win, and the hypothesis that treatment effects were the same throughout the baseline test score distribution cannot be rejected. The explanation for the gains among low-performing girls offered in Kremer et al. (2009) is that the incentives led to improved teacher and student effort that generated positive classroom externalities (including for boys, who also show moderate gains despite being ineligible for the scholarship). This is supported by the increases in both pupil and teacher attendance in treatment schools (Table 1, panel B).

\section{Data Collection, Estimation Strategy, and Programme Impact on Human Capital}

Follow-up data collection (2005-7)

To assess the persistence of these academic gains and other long-term impacts of the programme, a follow-up survey was undertaken from October 2005 to February 2007, approximately four to five years after the GSP competitions, when sample individuals were young women between 17 and 21 years of age. This involved tracking down the two cohorts of girls from both treatment and control schools. Because the original intervention was aimed at girls and the research budget was limited, the follow-up data collection sample was limited to females.

Respondents were followed by the survey team wherever they moved in Kenya or Uganda. During an initial phase, all individuals were tracked. In early 2007, a random subsample containing one-fifth of the remaining unfound respondents was drawn to be tracked 'intensively' (in time and travel costs). We re-weight the 'intensive' sample to maintain representativeness. As a result, all figures are 'effective' tracking rates (ETRs), calculated as a fraction of those found, or not found but searched for during intensive tracking, with appropriate weights. The ETR is a function of the regular phase tracking rate (RTR) and intensive tracking rate (ITR),

$$
\mathrm{ETR}=\mathrm{RTR}+(1-\mathrm{RTR}) * \mathrm{ITR},
$$

where RTR is $47.5 \%$ and ITR is $65.2 \%$. This follows the approach in the US Moving to Opportunity study (Kling et al. 2007).

\footnotetext{
${ }^{10}$ The effect size in the follow-up sample is similar to that in the original sample, but it is slightly less statistically significant in the follow-up sample because of the reduced sample size.

${ }^{11}$ While it is also possible to normalize separately within cohorts, here we normalized the entire sample together, and include cohort controls in all regressions, to simplify the exposition.
} 
Overall, $84.0 \%$ of respondents were effectively located by the field team, with $81.6 \%$ surveyed while $2.4 \%$ were deceased, refused to participate or were found but were unable to be surveyed (Table 2, panel A). The effective survey rate among those still alive is $82 \%$. These are quite high rates for a mobile young adult population, and places this project among the more successful longitudinal survey efforts in a low-income country (Thomas et al. 2012). The final analysis sample with baseline surveys and follow-up data includes 1387 girls.

There are no statistically significant differences in follow-up survey attrition across the treatment and control groups (Table 2, panel A). We also do not find that survey attrition over time is significantly related to the baseline 2000 test score, the presence of a toilet, iron roof, or mosquito net in the home compound, time spent on chores and schoolwork, schooling attitudes, and number of siblings, nor are these characteristics significant predictors of survey attrition when interacted with the treatment indicator (not shown), evidence that differential survey attrition across the treatment and control groups does not appear to be a leading concern. As with the baseline survey data, the follow-up subsample is balanced along observed baseline individual and household characteristics across the treatment versus control samples (Table 1, panel A).

Once respondents were located, enumerators administered short tests on English vocabulary, Swahili vocabulary, arithmetic, reading and spatial reasoning (using Raven's matrices). The survey also included questions on schooling, marriage, fertility, migration and social and political attitudes. To the extent possible, these latter questions were adapted from questions in the World Values Survey and Afrobarometer Surveys, building on Bratton et al. (2005), Logan and Bratton (2006) and Weakliem (2002), while some new questions were developed specifically for the Kenyan context. In the tables, we denote questions drawn from the World Values Survey with 'WVS' and Afrobarometer with 'AFB'. Indicator variables are denoted ' $0-1$ '. Questions asked on a four- or five-point scale were rescaled so the lowest (highest) answer takes on a value of zero (one), and these are denoted ' 0 to 1 ' in the tables.

\section{Estimation strategy}

We first estimate the impact of the GSP on outcomes (POLIT) in a reduced-form specification, by regressing POLIT on the indicator variable for GSP treatment schools (TREAT). We also include some additional control variables (denoted $X$ )—an indicator for student cohort, age at the time of the survey, parent educational attainment, and timing of the follow-up survey - to address any minor baseline differences between the treatment and controls schools that exist despite the randomization. Since the randomization successfully produced treatment and control groups balanced along most characteristics (Table 1), the inclusion of controls does not meaningfully alter estimates (see online Appendix Table A1) but can improve statistical precision. Equation (1) presents the reduced form:

$$
\operatorname{POLIT}_{i s}=\alpha+\beta \operatorname{TREAT}_{s}+X_{i s}^{\prime} \gamma+\varepsilon_{i s},
$$

where individual $i$ is in school $s$. The coefficient of interest is $\beta$. Disturbance terms are clustered by school. We employ OLS for both continuous and limited dependent variables in 
part to facilitate the use of the mean effects approach (described below), but results for indicator variable outcomes are nearly unchanged in probit specifications (not shown).

The GSP could potentially affect political attitudes through human capital or through other impacts of winning a scholarship, such as the cash transfers and public recognition received by winners. Recall that girls in the top $15 \%$ in the treatment schools won scholarships. Girls with normalized baseline test scores less than +2 standard deviations have just an $8 \%$ chance of winning the scholarship, as compared to $58 \%$ among girls with baseline scores above +2 standard deviations. ${ }^{12}$ These treatment school girls with lower baseline scores are thus unlikely to receive the prize and recognition, but Kremer et al. (2009) show that they nonetheless attend school more often and have test score gains. As discussed in Section V, estimating treatment effects in this subgroup arguably sheds light on the relative importance of the 'public recognition' and 'human capital' channels, suggesting that the human capital channel is important.

To convey a sense of the magnitude of the human capital effects, and to allow comparison of our experimental estimates with non-experimental estimates, we report IV estimates of the impact of human capital on political attitudes by using the follow-up test score measure as the endogenous variable, denoted $H$. We view the test score as an attractive summary measure of human capital. We focus on the normalized average test score across all subjects (arithmetic, English, Swahili, reading, spatial reasoning) as our best measure of overall skills and human capital, where the normalized variable has mean zero with a standard deviation of one (the common approach in the education literature). The first-stage equation is

$$
H_{i s}=a_{1}+b_{1} \operatorname{TREAT}_{s}+X_{i s}^{\prime} c_{1}+e_{1, i s} .
$$

The predicted values from this regression allow us to estimate human capital impacts in an instrumental variable two-stage least squares (IV-2SLS) specification, where the second stage is

$$
\operatorname{POLIT~}_{i s}=a_{2}+b_{2} H_{i s}+X_{i s}^{\prime} c_{2}+e_{2, i s}
$$

For comparison with observational studies, we also provide similar estimates but running the second stage equation (3) using the actual test score rather than the predicted score, while restricting attention to the control group to isolate non-experimental variation. For each set of outcomes, we then compare the analogous OLS and IV coefficient estimates, and compute the statistical significance of the difference between them using the Hausman test. Below we interpret differences between the OLS and IV estimates in the context of a model of endogenous schooling choices and individual willingness to accept authority. Note that the OLS and IV differences may also be the result of other factors beyond endogeneity,

\footnotetext{
${ }^{12}$ Approximately $2 \%$ of the girls score more than 2 standard deviations above the mean of the normalized distribution.
} 
including omitted variables, as well as the fact that the IV captures local average treatment effects (LATE), while OLS generates potentially biased estimates based on the entire sample; we return to issues of interpretation below.

For various categories of outcomes, we estimate the 'mean effect' of either GSP treatment or human capital on each set of outcomes following Kling et al. (2007). The groupings of related outcome variables are denoted by $Y_{k}, k=1, \ldots, K$. We standardize each outcome by subtracting the mean and dividing by the standard deviation of the outcome variable among the GSP control group, such that the control group mean (standard deviation) is zero (one).

The standardized variables are denoted $Y_{k}^{*}$. With these, we form $Y^{*}=\sum_{k} Y_{k}^{*} / K$, a single index of outcomes, and regress this index on TREAT (as in equation (1)) or on $H$ (equation (3)). The resulting coefficient estimate is the mean effect size, and due to the normalization, it captures the average impact in terms of standard deviations of the outcome variables. This normalization facilitates comparison of impact magnitudes across outcomes, as well as possibly across other studies.

\section{Impacts on human capital}

We first discuss the programme's impact on human capital. The human capital gains that occurred as girls competed for scholarships persisted in the 2005-7 follow-up survey, with significant test score gains in treatment schools relative to the control group (Table 2, panel B). In specifications analogous to the first-stage regression (equation (2)), test scores improved in all five subjects, with statistically significant gains in four subjects. The mean effect across all tests is 0.208 standard deviations (s.e. 0.092), which is significant at $95 \%$ confidence. This moderate test score gain is in line with the impacts generated by other primary education interventions in less developed countries (McEwan 2014).

Test score impacts are nearly unchanged among two subgroups with relatively low chances of actually winning a GSP award, namely those with baseline normalized test scores less than +2 standard deviations, at 0.145 standard deviations (s.e. 0.082), and among those in schools predicted to have five or fewer GSP winners, at 0.177 standard deviations (s.e. 0.081). The predicted number of GSP winners is estimated in treatment schools by regressing the actual number of winners on quantiles of the baseline test score distribution (among students in that school); the predicted number of winners is then assigned to both treatment and control schools. The persistent human capital gains that we document thus appear to be driven by competing for a scholarship rather than winning.

Beyond test scores, several other education measures also improved in the treatment group: they were 8.7 percentage points (s.e. 4.1) more likely to have attended at least some secondary school, a large increase of nearly one-third on the control rate of $30 \%$. GSP treatment individuals were also 7.9 percentage points more likely to be enrolled in school, an increase of $15 \%$ relative to the control group average of $52 \%$. Since more than half the sample was still in school, the attainment data are severely censored, and perhaps in part as a result, the programme is estimated to have a positive but not significant impact on educational attainment. 


\section{Impact on Autonomy Within the Household}

As discussed above, many argue that education empowers young women to address broader gender inequalities. Others argue that women in most societies face relatively less disadvantage in education than other spheres, and that efforts to reduce gender imbalances could be more productive elsewhere (Hausmann et al. 2010). Modernization theory would also imply that education should erode support for traditional gender roles.

We do not find significant changes in views regarding equal rights for women versus traditional gender roles (Table 3). Most respondents already strongly support gender equality, with average support for traditional roles (namely, the statement that 'Women have always been subject to traditional laws and customs and should remain so' as opposed to 'Women should have equal rights and receive the same treatment as men do') at only 0.17 on a normalized zero to one scale. ${ }^{13}$ Treatment reduces this by just 0.01 , and the effect is not statistically significant.

In contrast, treatment produces changes on two concrete issues limiting female autonomy that are likely to be personally relevant for many respondents: domestic violence and arranged marriages. Again on a zero to one scale, treatment leads to a 0.068 reduction (s.e. 0.024) in support for the claim that 'Men can beat their wives and children if they misbehave' as opposed to the statement that 'No one has the right to use physical violence against anyone else', a reduction of roughly one-quarter on average support of 0.25 in the control group.

We next consider marriage patterns, and divide marriages into 'arranged marriages', where parents played a role in spouse choice, and 'elopements', where they did not. Roughly $20 \%$ of respondents were married by the follow-up survey, with three-quarters being elopements in the control group, and one-quarter, or $4.2 \%$, arranged. However, this latter figure falls by more than half, or 2.4 percentage points (s.e. 1.3) in the treatment group (Table 3), and this effect is significant at $90 \%$ confidence. In contrast, we find no change in the likelihood of elopement, suggesting that the reduction in marriages with family involvement reflects not a broader trend in marriage rates but rather a shift in power from parents to their daughters. When we use a mean effects approach to look at a summary measure of lack of autonomy combining the two measures of support for traditional gender norms with the measure of arranged marriage, we find a significant reduction of -0.181 standard deviations (s.e. 0.077).

There are no significant programme impacts on fertility, or on knowledge of contraception, age of marriage, or basic spouse characteristics (not shown), although statistical power was limited in some cases, given the limited proportion of married women in the sample.

The results on young women's greater control over marriage patterns and stated opposition to domestic violence are not only relevant from a policy perspective but also shed light on the theories described in the Introduction. They are inconsistent with the idea that education

\footnotetext{
${ }^{13}$ There is some ambiguity in interpreting the second statement about equal rights, since even supporters of gender equality might advocate 'different treatment' for women in certain spheres, to take into account the different circumstances that they face (i.e. with regard to childbearing, etc.).
} 
simply instils greater acceptance of authority, but are compatible with both modernization theory and the view that education can empower disadvantaged groups. While these results are inconsistent with the simplest version of the theory, that education is a tool for entrenching existing power structures, they are arguably consistent with a more nuanced view, in which Kenya's education system is controlled not by traditional village elites, but rather by a state seeking to instil certain 'modern' values that weaken pre-capitalist 'fetters' on female labour. To distinguish between these two perspectives, we next consider impacts on political and social attitudes beyond the household.

\section{Impacts on Political and Social Attitudes}

In the first subsection of this section, we find little support for a direct impact of education in promoting 'modern' values. The second subsection reports evidence that runs counter to the view that education simply instils acceptance of existing authority, but is consistent with the notion that education promotes an awakening of political consciousness that is arguably the first step to actual empowerment, specifically through changes in media consumption, increased political knowledge and dissatisfaction with authority. However, the third subsection suggests that rather than translating into increased participation in politics or community affairs, or in social capital, these shifts generate greater expressed willingness to accept the use of violence in politics.

\section{Impact on 'modern' attitudes}

Impact on ethnic and religious attitudes-From a theoretical perspective, the impact of schooling on feelings of ethnic and religious identity is unclear. Modernization theory predicts that education will reduce particularistic ethnic attachments and promote secularism. Yet other scholars argue that in pre-colonial times, the most important groups were local 'sub-ethnic' kinship groups, with ethnic boundaries fairly fluid (Shetler 2010), and thus see contemporary notions of tribal identity (among groups such as the Luhya in our sample) as essentially modern. In this second view, education could potentially promote political mobilization along ethnic lines, although recall that the Kenyan curriculum seeks to promote nationalism. The standard Kenyan school curriculum also includes religious education, and schools often sponsor religious youth groups, so education could also potentially strengthen, rather than weaken, religious attachment.

We find no evidence that increased schooling weakened ethnic attachments, and if anything the programme may have strengthened them. In general, respondents were strongly attached to their own ethnic group, with only $11 \%$ of the control group not reporting ethnicity as 'very important' to them. GSP treatment reduced this by 3.3 percentage points, or approximately $30 \%$, although the difference is not significant (Table 4, panel A).

We next exploit the fact that ethnic identification is more salient closer to contested democratic elections in Africa (Eifert et al. 2010), likely because ethnic electoral appeals are widespread. We find that among the 43 respondents surveyed in early 2007-a national election year-all but one stated that their ethnic affiliation was 'very important' to them, far above the average among those surveyed earlier; this 'censoring' of responses suggests that our survey instrument was insufficiently sensitive to finer distinctions in the degree of ethnic 
feeling during election periods. We next focus on respondents surveyed in 2005-6, before the lead-up to the election, and find that treatment reduced the proportion who did not report ethnicity as 'very important' by a significant 4.2 percentage points (s.e. 2.1, Table 4), a $40 \%$ drop. In other words, in non-election years the programme appears to heighten feelings of ethnic identification.

A related set of questions on ethnicity asks whether respondents trust members of their own ethnic group (tribe) as well as members of other groups. Point estimates suggest treatment slightly increased trust in co-ethnics and reduced trust in members of other ethnic groups, but the effects were not significant at traditional confidence levels (not shown). We similarly find no programme impacts on migration out of the local area, which might have brought people into closer contact with other ethnic groups, thus leading to more inclusive ethnic attitudes, and which might itself be taken as reflecting more inclusive attitudes (not shown).

We also find no evidence for the modernization theory hypothesis that education leads to secularization as measured by changes in the reported importance of religion (Table 4, panel A), although strong religiosity is nearly universal, complicating inference. There is more variation in participation in prayer groups, but there, too, impacts are small and not statistically significant. ${ }^{14}$

Impact on democratic attitudes-Respondents were asked whether they agreed with a series of statements about the ideal organization of government and society, where responses were given on a scale from 1 to 5, ranging from 'strongly disagree' to 'strongly agree', and these were then normalized to range from zero to one, as above. To illustrate, respondents were asked whether they agreed with 'We should choose our leaders in this country through regular, open and honest elections' and 'Democracy is preferable to any other kind of government', among others.

There are no significant GSP impacts on any of the seven measures of democratic attitudes (Table 4, panel B), and even combining all of these effects together in a single index, the mean effect is small and not statistically significant, at 0.023 standard deviations (s.e. 0.098). These results are particularly interesting in light of the positive cross-sectional correlations between individual schooling and democratic attitudes documented in the existing literature, including several African studies (Bratton et al. 2005; Logan and Bratton 2006; Mattes and Bratton 2007). While some have argued that investments in education may be an effective way to promote democracy and reduce political extremism, our results suggest that if there is any such causal relationship, then it may not be a direct one.

Overall, we find no support for the hypothesis that education promotes 'modern' attitudes including weakening of ethnic attachments, secularization or greater belief in democracy. These findings partially alleviate concerns that more educated Kenyans are simply providing the 'right' survey answers due to social desirability bias. In particular, to the extent that support for democratic institutions is the 'politically correct' response in Kenya, we might have expected to find a strongly positive relationship between human capital and support for

${ }^{14}$ Glaeser and Sacerdote (2001) show that US religious attendance rises with education. 
democracy, but we find no such relationship in our data. We next examine whether education promotes empowerment in the political realm, consistent with the household autonomy results.

\section{Impact on media consumption, political knowledge and satisfaction}

The first hint that the programme affected political outcomes is its impact on media consumption. Individuals in treatment schools report significantly less time listening to radio —which in Kenya has largely music and entertainment content—and more days reading newspapers, which report extensively on national politics (Table 5, panel A). Respondents were also much more likely to identify a favourite newspaper, with an increase of 9.6 percentage points (s.e. 3.7) on a base of $66.6 \%$ in the control, and in particular, there was a large increase of 10.5 points (s.e. 3.5) in choosing the Daily Nation, arguably Kenya's most authoritative English language daily, as the favourite news source on a base of 30.5\%. The increased affinity for the Daily Nation almost certainly in part reflects the treatment group's improved English reading skills and ability to comprehend complicated content, but may also proxy for changing partisan or ideological tastes and will affect the quality of political information consumed.

Indeed, the programme had a large impact on objective political knowledge. Respondents were asked to name Kenya's President, Vice President, Education Minister and Health Minister, and Uganda's President. Virtually all respondents could name the President, but the programme increased the likelihood that respondents could name other officials, and the impacts are significant for naming the Health Minister and the President of Uganda (not shown). The mean effect across all five questions is 0.203 standard deviations and significant at $95 \%$ confidence (Table 5, panel B).

Turning to measures of satisfaction with political authorities, the GSP treatment group shows less deference to authority in the abstract, and expresses less satisfaction with Kenya's government, economy, democracy and current authorities (Table 5, panel C). In particular, respondents were significantly less likely to agree with the statement 'We should show more respect for authority' and more likely to support the statement 'As citizens, we should be more active in questioning the actions of our leaders', with a change of 0.076 in the normalized index, relative to a control group mean of 0.53 . When asked whether the quality of government and the economy were better than two years ago, treatment reduced positive assessments by 5.4 and 5.8 percentage points, respectively, both significant at $90 \%$. This despite the fact that Kenya's performance was good relative to historical benchmarks, with GDP growth of 6\% in 2006-7 and reasonably democratic politics. In control schools, satisfaction with Kenyan democracy was 0.74 (on a normalized 0 to 1 index), and treatment decreased this by 0.048 (s.e. 0.017). Taken together, expressed satisfaction falls in the treatment group by 0.239 standard deviations (significant at $99 \%$ ). This sharp reduction in satisfaction with political authority parallels the rejection of male and parental authority in the household (Table 3).

There is no evidence that the programme affected overall personal happiness, as captured by agreement with 'taking everything together, the respondent is very happy' (Table 5, panel C), and thus the political dissatisfaction questions do not simply reflect broader life 
dissatisfaction. Note that there is little consensus on the empirical relationship between education and happiness using OECD data (Frey and Stutzer 2002).

\section{Empowered for what? Perceived political efficacy, participation, and violence}

The increased knowledge and reduced satisfaction with authority generated by the programme does not seem to translate into greater perceived political efficacy or more participation in politics or community affairs. Instead, there is suggestive evidence of increased acceptance of the use of violence in politics.

Impact on perceived political efficacy-A large majority of respondents agreed with the statements 'Politics and government sometimes seem so complicated that you can't really understand what's going on' and 'This world is run by a few people in power, and there is not much that someone like me can do about it', and GSP treatment does not lead to a significant change from the low levels of perceived political efficacy in the control group (Table 6, panel A). Indeed, Kenyan politics at the time of the survey was characterized by Byzantine backroom deal-making among ethnically-based political leaders, many of whom were the sons of an earlier generation of leaders. While treatment made the young women in the sample less satisfied with the political situation (Table 5), it apparently did not lead to any illusions about their personal ability to change the situation.

Impact on political and community participation-The GSP did not increase interest or participation in politics or community affairs. In particular, $26 \%$ of control group respondents reported being interested in public affairs, versus $23 \%$ in treatment, although this difference is not statistically significant (Table 6, panel A). Similarly, treatment respondents of voting age were slightly less likely to report intending to vote in the next presidential election ( -2.6 percentage points, s.e. 4.5$)$, but the effect is not significant.

While some have argued that education enhances civic participation, we do not find evidence for this. The survey gathered information on membership in 10 common types of community groups (women's groups, credit groups, etc.), with average membership in 1.41 groups in the control. There is no treatment effect on membership (Table 6, panel B). The programme also had no impact on trust, in the standard question 'Generally speaking, would you say that most people can be trusted or that you need to be very careful in dealing with people?'.

Attitudes toward the use of violence in politics-Although Kenya has never experienced a civil war, it has a long record of ethnic violence around elections, going back to the first multi-party polls in 1992. As noted above, some observers have argued that education tends to reduce political violence, while others see it as raising expectations that, if unmet, could increase individuals' propensity towards violence (Davies 1974).

We find some suggestive evidence that the GSP led to greater expressed tolerance for political violence. Referring specifically to Kenyan politics, respondents were asked whether they agreed with the statement 'It is sometimes necessary to use violence in support of a just cause' or instead with 'The use of violence is never justified in politics'. ${ }^{15}$ Treatment individuals are significantly more likely to agree or strongly agree with the first statement 
(estimate 0.059 , s.e. 0.029 in Table 6, panel C), off a base of 0.23 in the control group. An alternative and continuous measure that incorporates variation in the strength of views yields a positive coefficient estimate that is also large in magnitude but not statistically significant at traditional confidence levels (estimate 0.040 , s.e. 0.028). Taken together, this constitutes suggestive evidence that education increases the perceived legitimacy of political violence.

It seems plausible that education could increase acceptance of violence because it increases respondents' political knowledge and reduces satisfaction with the status quo (as shown above), while not simultaneously increasing their faith in their ability to achieve change through democratic means. Since they are no more committed to democratic values as a result of education and, if anything, more ethnically identified - the key dimension of social conflict in Kenya-it may not be surprising that education increases support for political violence.

From one perspective, there appears to be a tension between the estimated impacts of education on views about the legitimacy of political violence and on domestic violence in our sample. However, both findings are consistent with the view that education reduces the automatic acceptance of existing authorities, both at home and in the political arena.

\section{Estimating the Bi-directional Relationship Between Schooling and Attitudes}

As discussed in the Introduction, some argue that education indoctrinates people to accept existing authority, whereas others argue that it can empower people to challenge authority. Our results in the context of the GSP and taking advantage of experimental variation provide considerable support for the hypothesis that education reduces willingness to accept authority. In this section, we argue that our data are consistent with a bi-directional relationship between education and willingness to accept authority - in which those who are unwilling to accept authority are more likely to withdraw from education, while education itself leads to questioning of authority — and that such a relationship could lead nonexperimental analyses to understate the extent to which education leads to less acceptance of authority.

In the first subsection of this section, we present a simple model in which there is a bidirectional relationship between education and willingness to accept authority, and show that in this model standard approaches to estimate the impact of education on acceptance of authority using regressions in non-experimental data will yield biased estimates if - as is particularly plausible in schooling systems such as those of Kenya, which do not allow much room for student autonomy - those who are less willing to accept authority are more likely to drop out of school. As discussed in the Introduction, there is an extensive literature

\footnotetext{
${ }^{15}$ The exact survey wording and coding is as follows.

'Read: For each of the following pairs of statements, tell me which of the following statements is closest to your view about Kenyan politics? Choose Statement A or Statement B. Probe: Do you agree or disagree very strongly?

A. The use of violence is never justified in politics.

B. In this country, it is sometimes necessary to use violence in support of a just cause.

$1=$ Agree very strongly with A; $2=$ Agree with A; $3=$ Agree with B; $4=$ Agree very strongly with B; [DO NOT READ] $5=$ Agree with neither; $99=$ Don't know.'
} 
documenting non-experimental correlations between individual education a range of political attitudes, including towards political authorities, in Africa (e.g. Bratton et al. 2005; Mattes and Bratton 2007). In the second subsection, we use the non-experimental variation in our data to estimate the extent of reverse causality, in which willingness to accept authority allows people to obtain more education, and discuss the resulting bias that would be created in non-experimental estimates in our context.

\section{A model of the relationship between schooling and willingness to accept authority}

We consider a framework in which education can affect willingness to accept authority, and willingness to accept authority can affect schooling decisions. Suppose that

$$
R_{1}=R_{0}+\gamma H
$$

where $R_{1}$ is willingness to accept authority as an adult, and $R_{0}$ is willingness to accept authority as a child. $H$ is a measure of human capital investment, and $\gamma$ is thus the causal impact of education on willingness to accept authority. Suppose that household $i$ chooses human capital to trade off the benefits versus the net utility and financial costs of education:

$$
U_{i}=B\left(H_{i}\right)-C\left(H_{i}\right) .
$$

We assume that being in a school that has the merit scholarship programme raises the benefit of human capital $(B)$, because those who score well on the exam will receive financial benefits. We also assume that individuals may differ in the benefit that they experience, for example, due to differences in non-pecuniary benefits of education or differences among children in aptitude or attitudes toward school. One component of this may be a difference in willingness to accept authority, and we allow for the possibility that $R_{0}$ may also affect the cost of education. Recall that in our context, being in school requires acceptance of a great deal of authority, including acceptance of the right of teachers to impose work (such as cleaning the classroom or carrying items for the teachers), orders from student prefects, and corporal punishment. Students who are unwilling to accept the fairly rigid discipline associated with Kenyan education often have to leave school, with perhaps the most notable example for non-Kenyans being Barack Obama Sr, who, despite his stellar grades, was expelled from an elite secondary school for what was deemed 'disrespectful' behaviour towards his teachers (Jacobs 2011).

For simplicity, we take the benefits to be linear in the amount of education $(H)$, and the cost of education to be quadratic in $H$. Thus we specialize to the case in which for household $i$,

$$
U_{i}=H_{i}\left(B_{0, i}+\beta_{1} R_{0, i}+\beta_{2} M_{i}\right)-H_{i}^{2},
$$

where $R_{0, i}$ indicates a child's willingness to accept authority, $M_{i}$ is an indicator for attending a merit scholarship programme school, and $B_{0}$ indicates an individual's other benefits of 
education (per year of schooling). We assume that children's willingness to accept authority is distributed normally with mean $\bar{R}_{0}$ and variance $\sigma_{R}^{2}$, and that the benefits are distributed normally with mean $\overline{B_{0}}$ and variance $\sigma_{B}^{2}$. These are distributed independently for simplicity (although this could easily be weakened). The optimal level of human capital investment for household $i, H_{i}^{*}$ is determined by the first-order condition

$$
H_{i}^{*}=\left(B_{0, i}+\beta_{1} R_{0, i}+\beta_{2} M_{i}\right) / 2
$$

This implies that, ceteris paribus, for each increase of one unit in a child's willingness to accept authority, there is an increase of $\beta_{1} / 2$ in the human capital investment optimally chosen.

It is straightforward to see that a regression of willingness to accept authority on education will not yield a causal estimate of the impact of education in this environment with bidirectional causality. In the case where there is no merit scholarship, an OLS regression of willingness to accept authority on human capital will yield the following coefficient (see the online model appendix for the algebraic details):

$$
\gamma_{\mathrm{OLS}}=\frac{\operatorname{Cov}\left(R_{1, i}, H_{i}^{*}\right)}{\operatorname{Var}\left(H_{i}^{*}\right)}=\gamma+\frac{2 \beta_{1} \sigma_{R}^{2}}{\sigma_{B}^{2}+\beta_{1} \sigma_{R}^{2}} .
$$

In this case, the term

$$
\frac{2 \beta_{1} \sigma_{R}^{2}}{\sigma_{B}^{2}+\beta_{1} \sigma_{R}^{2}}
$$

represents the bias in the OLS estimate, and from equation (8), we can see that the OLS estimator is biased upwards, leading to an erroneous view that education leads to a more positive impact on the willingness to accept authority than is actually the case.

Now consider the case in which a merit scholarship programme is introduced in a randomly chosen subset of schools. By construction, $M_{i}$ is orthogonal to $R_{0, i}$ and $B_{0, i}$. Using the merit scholarship as an instrument for human capital, $H_{j}$, would generate an unbiased estimate of the causal impact since merit scholarships are independent of initial willingness to accept authority and of other determinants of the return to education:

$$
\gamma_{\mathrm{IV}}=\frac{\operatorname{Cov}\left(R_{1, i}, M_{i}\right)}{\operatorname{Cov}\left(H_{i}^{*}, M_{i}\right)}=\frac{\gamma\left(\beta_{2} / 2\right) \operatorname{Var}\left(M_{i}\right)}{\left(\beta_{2} / 2\right) \operatorname{Var}\left(M_{i}\right)}=\gamma .
$$

Taking the difference between the OLS and IV estimates allows us to solve for $\beta_{1}$ in terms of known parameters estimated in our data (algebraic details again in the online Appendix): 


$$
\beta_{1}=1 /\left(\frac{\sigma_{R_{1}}^{2}-\gamma_{\mathrm{IV}}^{2} \sigma_{H}^{2}}{2\left(\gamma_{\mathrm{OLS}}-\gamma_{\mathrm{IV}}\right) \sigma_{H}^{2}}-\gamma_{\mathrm{IV}}\right)
$$

\section{Comparing the experimental and non-experimental relationships}

To empirically compare experimental and non-experimental results, the extent to which willingness to accept authority affects education, and the extent to which education affects acceptance of authority, we first reproduce the main reduced-form impacts (from Tables 36) in column (1) of Table 7, then present IV estimates in column (2) and non-experimental OLS estimates (for the control group) in column (3). Column (4) presents $p$-values on the Hausman test of equality of the IV and OLS estimates. We find it useful to view these differences in the context of our model of schooling choices, but as mentioned above, interpretation is somewhat complicated by omitted variables and the local nature of the IV estimate (which captures effects among 'compliers').

For the lack of autonomy index, the IV coefficient estimate implies that a one standard deviation increase in the normalized test score (in the 2005-7 survey) is associated with an effect of -0.872 standard deviations (s.e. 0.493), a large effect. To put this in context, a one standard deviation test score increase in this population is more than the gain observed (in the cross-section) by advancing by one primary school grade. This contrasts with an OLS estimate of just -0.286 , thus the IV estimate is nearly three times as large as the OLS estimate. We nearly reject equality of the experimental and non-experimental estimates at $90 \%$ confidence ( $p$-value 0.11 ).

The IV estimate for the impact of education on satisfaction with authority index is also large and negative $(-1.149$, s.e. 0.494$)$ and significant at $95 \%$ confidence, while the OLS estimate is just -0.177 , and the difference between the two is significant at $99 \%$ confidence. This divergence mirrors the findings above for the lack of autonomy index: both of these measures capture opposition to existing authorities, one in the home and the other in the broader political arena. The difference between the IV and OLS estimates is substantively large: while both have the same sign, the IV estimate is six times larger in magnitude and leads to different conclusions about the relationship between education and the willingness to accept authority.

Under the model sketched above, it is possible to solve for the impact of willingness to accept authority on education. Since both test scores and the satisfaction of authority index are normalized so that the variance is 1 , we have

$$
\begin{aligned}
& \beta_{1}=1 /\left(\frac{\sigma_{R_{1}}^{2}-\gamma_{\mathrm{IV}}^{2} \sigma_{H}^{2}}{2\left(\gamma_{\mathrm{OLS}}-\gamma_{\mathrm{IV}}\right) \sigma_{H}^{2}}-\gamma_{\mathrm{IV}}\right) \\
& =1 /\left(\frac{1^{2}-(-1.149)^{2} 1^{2}}{2(-0.177-(-1.149)) 1^{2}}-(-1.149)\right)=1.016 .
\end{aligned}
$$

Economica. Author manuscript; available in PMC 2017 October 06. 
Thus in equilibrium, individuals who are one standard deviation more willing to accept authority accumulate $\beta_{1} / 2$ or 0.508 standard deviations more human capital as measured by tests. This indicates that, all else equal, those pupils who are unwilling to accept authority are likely to invest less in education, consistent with a growing literature on the importance of individual personality traits as determinants of educational, labour market and other life outcomes (Heckman et al. 2006).

In our data, an analysis that does not allow for the bi-directional effect or account for selection-namely, the OLS estimates in the control group - does not imply that education increases the willingness to accept authority (Table 7), but we argue that the magnitude of the effect of education in reducing acceptance of authority is biased greatly towards zero in this case. However, as can be seen from equation (8), the model suggests that in other environments where baseline variation in willingness to accept authority $\left(\sigma_{R}^{2}\right)$ is greater, or other sources of variation in returns to education $\left(\sigma_{B}^{2}\right)$ are smaller, the bias in nonexperimental estimates would be greater, potentially leading to the erroneous conclusion that education increases willingness to accept authority. Perhaps one of the reasons why some scholars have believed that education promotes acceptance of authority is that they have simply compared individuals with different levels of education without taking selection into account.

The above point estimate of the impact of willingness to accept authority on education is specific to the particular assumptions of the model, for example, to our specification of the functional form of the relationship between willingness to accept authority as a child and a young adult, and of the cost function for education. However, the findings that education reduces the willingness to accept authority by much more than would be thought based on regression analysis in non-experimental data, that the willingness to accept authority increases educational attainment, and that in situations with more baseline variation in willingness to accept authority a naïve cross-sectional analysis could lead to the 'wrong sign', namely the erroneous conclusion that education increases the willingness to accept authority, are all more general.

Other differences in OLS and IV estimates are consistent with the model above. There is a significant difference in IV and OLS estimates of the impact of human capital on willingness to support political violence ( $p$-value 0.04 ), where OLS estimates are again biased towards zero.

There is no evidence that attitudes toward ethnicity, religion or democracy affect education. In particular, there are no statistically significant differences between the IV and OLS estimates for ethnic, religious or democratic attitudes (with $p$-values of $0.11,0.43$ and 0.52 , respectively). However, it should be noted that the OLS relationship between human capital and democratic attitudes is significant at $99 \%$ confidence, consistent with many other observational studies discussed earlier. For the measures of newspaper reading and political knowledge, the coefficient estimates are positive and significant in both the IV and OLS cases, although IV estimates are larger in magnitude, and the difference between IV and OLS is significant at $90 \%$ for the political knowledge index. The estimated impacts on the 
perceived political efficacy index and the participation in politics index are near zero and not statistically significant for either the IV or OLS specifications, and there are no significant differences between them (with $p$-values of 0.31 and 0.56 , respectively).

Taken together, we reject the hypothesis that the IV and OLS estimates are equal for three of the ten dependent variables in Table 7 at $90 \%$ confidence (with two other $p$-values equal to 0.11 ), far more often than would be generated by chance alone under the null hypotheses that both were measuring the same underlying parameters. These large differences between non-experimental and experimental estimates suggest that it is important to carefully distinguish treatment versus selection effects in assessing whether education instils greater willingness to accept authority, or changes in other political attitudes and behaviours, and point to the importance of research strategies that exploit experimental or quasi-experimental designs.

\section{Understanding the Channels of Impact}

One could entertain several hypotheses about the channels of impact. Beyond the leading explanation of a human capital effect, scholarship winners received a cash prize and the girls were honoured in a public ceremony that could have affected their self-image and confidence. Changes in teacher engagement and behaviour, documented in Kremer et al. (2009), could also have had lasting effects on girls' status and self-image in the treatment schools.

It is important to note up front that the study's research design makes it impossible to definitively disentangle these various channels, since they are all 'bundled' together in the treatment schools. With that caveat in mind, in this section we provide some suggestive evidence that the human capital channel is likely to be an important mechanism in this setting. We do this by testing whether subsamples that were very unlikely to win a scholarship — and thus unlikely to receive the gain in social status due to the cash prize and award ceremony accorded to winners-also exhibited effects similar to those documented above. This is not a definitive test, since we cannot rule out the possibility that observing other girls being financially and socially rewarded for their efforts may help to change the perceived status of girls in both the household and the classroom, but we find that the patterns below taken together make the human capital interpretation more likely. Note that the interpretation of the reduced-form results remains unchanged, and this quantity-the overall effect of a girls' scholarship programme-is of intellectual and policy interest in its own right.

The main results are similar when we restrict attention to those individuals with baseline 2000 test scores below +2 standard deviations (online Appendix Table A2), suggesting that the findings are not being driven by scholarship winners, although note that standard errors do inevitably rise with the reduced sample size. We focus on our main outcome measures in this table. The estimated lack of autonomy effect in this restricted subsample is almost identical to the full sample effect, at -0.176 (s.e. 0.091 ). The satisfaction with authority mean effect is also similar ( -0.147 , s.e. 0.088$)$, and we cannot reject that it is equal to the full sample estimate. As in the full sample, there are no significant impacts on 'modern' 
ethnic, religious or democratic attitudes, or on individuals' perceived political efficacy or participation in civic affairs. The estimated programme impact on measures of newspaper reading, political knowledge and attitudes towards political violence remain positive but are somewhat smaller in magnitude and not significant in the restricted subsample. When we examine estimates across the two samples (namely, all those with baseline test scores vs. those with scores less than +2 standard deviations), in no case is the difference significant at even $90 \%$ confidence. $^{16}$

Another hypothesis is that the impacts are due in part to school-wide changes in attitudes associated with the implementation of a scholarship programme, if the experience of observing other girls being publicly recognized for their achievements changed norms. We cannot completely rule this out. However, there is no strong evidence in favour of this alternative view. While one could perhaps tell a story where having a programme that provided scholarships to girls led to more progressive gender attitudes (and thus could account for some of the autonomy findings in Table 3), it is harder to imagine why this would generate some of the other findings, for instance, in terms of newspaper reading, objective political knowledge, expressed satisfaction with political authority, or violence in politics.

Moreover, it seems reasonable to conjecture that any school-wide effects of the programme on gender attitudes would depend on the number of girls who were publicly recognized for their academic achievement. Because scholarships were awarded to girls scoring in the top $15 \%$ in the district, and there is considerable school-to-school variation in test scores, there are large differences in the numbers of winners across schools (for instance, 16 of the 34 treatment schools had no winners in 2001). As above, we create a measure of predicted GSP winners in both treatment and control schools. We find no compelling evidence of differences in the magnitudes of programme impacts across schools with different numbers of predicted winners (online Appendix Table A3. In particular, the interaction terms between treatment and predicted winners are significant for just two of the ten outcomes, while for the other eight variables the $t$-statistic is less than one. These generally small and not significant estimates suggest that non-human capital channels are not driving the results, although as noted above, we cannot rule out this possibility.

\section{Conclusion}

We examine the impact of increased human capital on political and social attitudes among young Kenyan women. Our experimental results contribute to a vast and mostly nonexperimental literature on the relationship between education and political and social attitudes, a relationship that is of particular interest in less developed societies like Kenya that have experienced rapid educational gains in recent decades. The programme leads young women to reject the legitimacy of domestic violence, and reduces their propensity to enter into marriages arranged by their parents. In findings that go against some claims in

\footnotetext{
${ }^{16}$ We are unable to decompose the human capital effect into the separate channels of primary school attendance (Table 1), secondary enrolment, and skills measured in tests (Table 2), since we lack separate instruments for these channels.
} 
modernization theory, the programme does not weaken ethnic attachment, promote secularization or increase stated support for democracy.

Consistent with the view that education can potentially enhance political consciousness, and contrary to theories suggesting that education merely instils acceptance of existing authority, programme participation leads to greater objective political knowledge and newspaper readership, less willingness to defer to authority and reduced satisfaction with Kenya's political and economic situation. However, this does not translate into greater perceived political efficacy, higher rates of voting or other forms of civic participation. This combination of heightened political awareness and reduced acceptance of the legitimacy of existing political structures, in an environment where respondents perceive little ability to effect change through Kenya's nascent democratic institutions, may help to explain the suggestive evidence that education was also associated with greater acceptance of the use of political violence. The fact that a programme that led to moderate educational impactsnamely, average test score gains of 0.2 standard deviations and an increase of one-third in secondary school enrolment_-generated such meaningful impacts on social and political attitudes is noteworthy, and raises the possibility that larger shifts in education could have even more transformative effects.

One possible interpretation is that education allowed young Kenyans to hold more realistic views about their political system. As noted above, less than one year after our surveys were collected, Kenya held a national presidential election in which independent observers argued that the main opposition candidate-who received the vast majority of votes in our study area-won more votes but the incumbent claimed victory after vote rigging (Gibson and Long 2009). After months of violent protests and bloody ethnic clashes, a power-sharing deal was reached under which the incumbent remained president and the challenger became prime minister. As individuals in our sample received more education, their declining satisfaction with the status quo and growing acceptance of political violence arguably reflects their growing awareness of the role that violence often plays in Kenyan politics.

Experimental and non-experimental estimates of the impact of education on acceptance of authority differ considerably, suggesting that observational cross-sectional correlations are biased. To make sense of these differences, we hypothesize that one's ability to stay in school is closely related to her willingness to accept authority, which leads to omitted variable bias in non-experimental estimates that could lead observers to erroneously conclude that education instils greater acceptance of authority. In the context of a simple model, we assess the extent of reverse causality, which appears to be considerable.

Somewhat ironically, it appears that only those who are sufficiently willing to accept a loss of autonomy when young (to succeed in school) actually have the opportunity to experience the gains in autonomy that education generates later in life.

Estimating these causal effects of education is, we believe, a useful step towards better understanding the positive cross-country empirical association between education and democracy. While interpretation of that relationship remains controversial, the results suggest that if education does lead societies to be more democratic, it is not necessarily through growing pro-democratic attitudes. Rather, the presence of an educated, well- 
informed and critical citizenry could lead democracies to function more successfully. Recent research argues that, regardless of individuals' support for democracy per se, a necessary foundation for a successful democratic system is the existence of politically knowledgeable and engaged citizens willing to actively participate in political life and challenge political authorities (Moehler 2008; Glaeser et al. 2007). Alternatively, the higher levels of political dissatisfaction generated by rising education could hasten the replacement of nondemocratic regimes.

\section{Supplementary Material}

Refer to Web version on PubMed Central for supplementary material.

\section{Acknowledgments}

We thank seminar audiences at Stanford University, the Working Group for African Political Economy meeting at Berkeley, the JICA Conference on Ethnic Diversity and Economic Instability in Kenya, the Oxford Centre for the Study of African Economies Conference, and University of Virginia for helpful comments. We appreciate helpful comments from Daron Acemoglu, Abhijit Banerjee, Marcel Fafchamps, Ray Fisman, Nahomi Ichino and Dan Posner, and two anonymous referees. Kenny Ajayi, Blastus Bwire, Lorenzo Casaburi, Garret Christensen, Joan Hamory Hicks and Owen Ozier provided excellent research assistance. We are grateful to the National Institutes of Health, National Science Foundation and Social Science Research Council for generous research support. The usual disclaimer applies.

\section{References}

Acemoglu D, Johnson S, Robinson JA, Yared P. From education to democracy? American Economic Review. 2005; 95(2):44-9.

Acemoglu D, Johnson S, Robinson JA, Yared P. Income and democracy. American Economic Review. 2008; 98(3):808-42.

Almond, G., Verba, S. The Civic Culture: Political Attitudes and Democracy in Five Nations. Thousand Oaks, CA: Sage Publications; 1963.

Barro R, Lee JW. International data on educational attainment: updates and implications. Oxford Economic Papers. 2001; 53(3):541-63.

Basu, A., King, EM. Does education promote growth and democracy?. In: Whitehead, L., editor. Emerging Market Democracies: East Asia and Latin America. Baltimore, MD: Johns Hopkins University Press; 2002. p. 152-81.

Blaydes, L. Who votes in authoritarian elections and why? Determinants of voting in contemporary Egypt. Paper presented at 2006 Annual Meeting of the American Political Science Association; 2006.

Boix, C. IBEI Working Paper no. 2009/26. 2009. Development and democratization.

Boix C, Stokes S. Endogenous democratization. World Politics. 2003; 55(4):517-49.

Bowles, S., Gintis, H. Schooling in Capitalist America: Educational Reform and the Contradictions of Economic Life. New York: Basic Books; 1976.

Bratton, M., Mattes, R., Gyimah-Boadi, E. Public Opinion in Africa: Learning About Democracy and Market Reform. Cambridge: Cambridge University Press; 2005.

Croke, K., Grossman, G., Larreguy, H., Marshall, J. Unpublished working paper. 2015. Deliberate disengagement: how education can decrease political participation in electoral authoritarian regimes.

Dahl, RA. Polyarchy: Participation and Opposition. New Haven, CT: Yale University Press; 1973.

Davies J. The J-curve and power struggle theories of collective violence. American Sociological Review. 1974; 39(4):607-10.

Dee T. Are there civic returns to education? Journal of Public Economics. 2004; 88(9):1697-720. 
Duflo E. Women empowerment and economic development. Journal of Economic Literature. 2012; 50(4):1051-79.

Eifert B, Miguel E, Posner D. Political competition and ethnic identification in Africa. American Journal of Political Science. 2010; 54(2):494-510.

Epstein D, Bates R, Goldstone J, Kirstensen I, O’Halloran S. Democratic transitions. American Journal of Political Science. 2006; 50(3):551-69.

Evans, D., Kremer, M., Ngatia, M. Unpublished working paper. 2010. The impact of distributing school uniforms on children's education in Kenya.

FIDA. Domestic Violence in Kenya. Nairobi: Federation of Women Lawyers of Kenya; 2008.

Filmer D, Schady N. Getting girls into school: evidence from a scholarship program in Cambodia. Economic Development and Cultural Change. 2008; 56(3):581-617.

Freire, P. Pedagogy of the Oppressed. Harmondsworth: Penguin; 1972.

Frey BS, Stutzer A. What can economists learn from happiness research? Journal of Economic Literature. 2002; 40(2):402-35.

Galston WA. Political knowledge, political engagement and civic education. Annual Review of Political Science. 2001; 4(1):217-34.

Gathigah, M. Inter Press Service. 2010 Dec 21. Politics: women still a parliamentary minority in Kenya.

Gibson C, Long J. The presidential and parliamentary elections in Kenya, December 2007: evidence from an exit poll. Electoral Studies. 2009; 28(3):497-502.

Glaeser, EL., Sacerdote, B. NBER Working Paper no. 8080. 2001. Education and religion.

Glaeser EL, Ponzetto G, Shleifer A. Why does democracy need education? Journal of Economic Growth. 2007; 12(2):77-99.

Gottlieb, J. Unpublished working paper. 2015. Why might information exacerbate the gender gap in civic participation? Evidence from Mali.

Gramsci, A. Selections from the Prison Notebooks. Smith, GN., editor. New York: International Publishers Co; 1971.

Gulesci, S., Meyersson, E. Unpublished working paper. 2012. For the love of the republic: education, religion, and empowerment.

Hanushek, E. Publicly provided education. In: Auerbach, A., Feldstein, M., editors. The Handbook of Public Economics. Vol. 3. Amsterdam: Elsevier; 2002. p. 2015-41.

Hausmann, R., Tyson, LD., Zahidi, S. The Global Gender Gap Report. Geneva: World Economic Forum; 2010.

Heckman J. The economics, technology, and neuroscience of capability formation. Proceedings of the National Academy of Sciences. 2007; 104(33):13,250-5.

Heckman J, Stixrud J, Urzua S. The effects of cognitive and noncognitive abilities on labor market outcomes and social behavior. Journal of Labor Economics. 2006; 24(3):411-82.

Herz, B., Sperling, GB. What Works in Girls' Education: Evidence and Policies from the Developing World. New York: Council on Foreign Relations; 2004.

Hochschild, A. King Leopold's Ghost: A Story of Greed, Terror and Heroism in Colonial Africa. New York: Mariner Books; 1999.

Human Rights Watch. Spare the Child: Corporal Punishment in Kenyan Schools. New York: Human Rights Watch; 1999.

Huntington, S. The Third Wave: Democratization in the Late Twentieth Century. Norman, OK: University of Oklahoma Press; 1991.

Iqbal, F., Riad, N. Increasing girls' school enrollment in the Arab republic of Egypt. Reducing Poverty, Sustaining Growth: What Works, What Doesn't, and Why. A Global Exchange for Scaling Up Success: Scaling Up Poverty Reduction. A Global Learning Process and Conference; Shanghai. 25-7 May; Washington, DC: World Bank; 2004.

Jacobs, SH. The Other Barack: The Bold and Reckless Life of President Obama's Father. New York: Public Affairs Press; 2011.

Jakiela P, Miguel E, te Velde V. You've earned it: estimating the impact of human capital on social preferences. Experimental Economics. 2014; 18(3):1-23. 
Kling J, Liebman J, Katz L. Experimental analysis of neighborhood effects. Econometrica. 2007; 75(1):83-119.

Kremer M, Miguel E, Thornton R. Incentives to learn. Review of Economics and Statistics. 2009; 91(3):437-56.

Kremer, M., Sarychev, A. Unpublished working paper. 2008. Why do governments operate schools?.

Krueger A, Maleckova J. Education, poverty, and terrorism: is there a causal connection? Journal of Economic Perspectives. 2003; 17(4):119-44.

Larreguy, H., Marshall, J. Unpublished working paper. 2015. The effect of education on civic and political engagement in non-consolidated democracies: evidence from Nigeria.

Levine, R., Lloyd, C., Greene, M., Grown, C. Girls Count: A Global Investment and Action Agenda. Washington, DC: Center for Global Development; 2008.

Levy, M. Modernization and the Structure of Society. Princeton, NJ: Princeton University Press; 1966.

Lipset SM. Some social requisites of democracy: economic development and political legitimacy. American Political Science Review. 1959; 53(1):69-105.

Lochner, L. NBER Working Paper no. 16722. 2011. Non-production benefits of education: crime, health, and good citizenship.

Logan, C., Bratton, M. Afrobarometer Working Paper no. 58. 2006. The political gender gap in Africa: similar attitudes, different behaviors.

Lott J Jr. Public schooling, indoctrination and totalitarianism. Journal of Political Economy. 1999; 107(S6):S127-S157.

Mattes R, Bratton M. Learning about democracy in Africa: awareness, performance, and experience. American Journal of Political Science. 2007; 51(1):192-217.

McEwan P. Improving learning in primary schools of developing countries: a meta-analysis of randomized experiments. Review of Educational Research. 2014; 85(3):353-94.

Miller A, Bolce L, Halligan M. The J-curve theory and black urban riots: an empirical test of progressive relative deprivation theory. American Political Science Review. 1977; 71(3):964-82.

Milligan K, Moretti E, Oreopoulous P. Does education improve citizenship? Evidence from the United States and the United Kingdom. Journal of Public Economics. 2004; 88(9):1667-95.

Mocan, NH., Cannonier, C. NBER Working Paper no. 18016. 2012. Empowering women through education: evidence from Sierra Leone.

Moehler, D. Distrusting Democrats: Outcomes of Participatory Constitution Making. Ann Arbor, MI: University of Michigan Press; 2008.

Nyerere, J. Freedom and Development. Dar-es-Salaam: Oxford University Press; 1973.

Oreopoulos P, Salvanes KG. Priceless: the nonpecuniary benefits of schooling. Journal of Economic Perspectives. 2011; 25(1):159-84.

Papaioannou E, Siourounis G. Economic and social factors driving the third wave of democratization. Journal of Comparative Economics. 2008; 36(3):365-87.

Przeworski A, Limongi F. Modernization: theories and facts. World Politics. 1997; 49(2):155-83.

Rynor J, Wesson K. The girl's stipend program in Bangladesh. Journal of Education in International Development. 2006; 2(2):1-12.

Shetler JB. Historical memory as a foundation for peace: network formation and ethnic identity in North Mara, Tanzania. Journal of Peace Research. 2010; 47(5):639-50.

Smith, SC., Emran, MS., Maret, F. Unpublished working paper. 2009. Education and freedom of choice: evidence from arranged marriages in Vietnam.

Sondheimer RM, Green DP. Using experiments to estimate the effects of education on voter turnout. American Journal of Political Science. 2010; 54(1):174-89.

Thomas D, et al. Cutting the costs of attrition: results from the Indonesia Family Life Survey. Journal of Development Economics. 2012; 98(1):108-23. [PubMed: 25705070]

UNDP. Human Development Report 1993. New York: Oxford University Press; 1993.

UNDP. Human Development Report 2009. New York: Oxford University Press; 2009.

UNDP. Human Development Report 2010. New York: Oxford University Press; 2010.

Economica. Author manuscript; available in PMC 2017 October 06. 
Verba, S., Nie, NH. Participation in America: Political Democracy and Social Equality. New York: Harper and Row; 1972.

Wantchekon L. Clientelism and voting behavior: evidence from a field experiment in Benin. World Politics. 2003; 55(3):399-422.

Wantchekon L, Klasnja M, Novta N. Education and human capital externalities: evidence from colonial Benin. Quarterly Journal of Economics. 2015; 130(2):703-57.

Weakliem D. The effects of education on political opinions: an international study. International Journal of Public Opinion Research. 2002; 14(2):141-57.

Weber, E. Peasants into Frenchmen: the modernization of rural France, 1870-1914. Redwood City, CA: Stanford University Press; 1976.

Were, G., editor. Kenya Socio-cultural Profiles: Busia District. Nairobi: Ministry of Planning and National Development, Government of Kenya; 1986.

Wolfinger, RE., Rosenstone, SJ. Who Votes?. New Haven, CT: Yale University Press; 1980.

Woodson, CG. The Education of the Negro Prior to 1861. New York: G. P. Putnam's Sons; 1915. 


\section{Table 1}

Girls' Scholarship Programme Baseline Characteristics and Short-run Impacts (2001-2)

\begin{tabular}{|c|c|c|}
\hline Dependent variable & $\begin{array}{c}\text { Comparison group variable mean } \\
\text { (s.d.) }\end{array}$ & $\begin{array}{c}\text { Coefficient estimate (s.e.) on programme } \\
\text { indicator }\end{array}$ \\
\hline \multicolumn{3}{|l|}{ Panel A: Baseline characteristics (2001-2 surveys) } \\
\hline Student age (2001) & $13.3(1.44)$ & $-0.14(0.15)$ \\
\hline Iron roof ownership & $0.82(0.38)$ & $-0.048(0.038)$ \\
\hline Mother years of schooling & $8.71(4.18)$ & $0.79 *(0.40)$ \\
\hline Father years of schooling & $10.47(3.99)$ & $0.55(0.49)$ \\
\hline Proportion ethnic Luhya & $0.79(0.41)$ & $0.067(0.056)$ \\
\hline Proportion ethnic Luo & $0.104(0.31)$ & $-0.054(0.038)$ \\
\hline Proportion ethnic Teso & $0.055(0.23)$ & $0.018(0.033)$ \\
\hline Test score pre-programme, all subjects (normalized) & $0.00(1.00)$ & $0.12(0.20)$ \\
\hline \multicolumn{3}{|l|}{ Panel B: Short-run impacts (2001-2) } \\
\hline Test score post-programme, all subjects (normalized) & $0.00(1.00)$ & $0.34 *(0.20)$ \\
\hline Student school attendance & $0.788(0.36)$ & $0.060 *(0.032)$ \\
\hline Teacher school attendance & $0.822(0.262)$ & $0.069 * * *(0.025)$ \\
\hline
\end{tabular}

Notes

Each row is from a separate OLS regression. Significant at $90 \%(*), 95 \%(* *), 99 \%(* * *)$ confidence.

The outcome variable is regressed on the GSP (treatment) indicator. Standard errors are clustered by school. The sample size in panel A ranges from 789 to 1387 observations depending on the dependent variable. The sample consists of female students in the GSP schools in Busia who were interviewed in the long-run follow-up and will be included in subsequent analysis. The academic subjects tested included English, geography/ history/civics, mathematics, science and Swahili. The attendance data for both pupils and teachers were collected during unannounced visits to schools in 2001 and 2002. The sample size in panel B is 993 students in the test score regressions, and 1351 students and 666 teachers in the attendance regressions, respectively. 


\section{Table 2}

Educational Outcomes in Follow-up survey (2005-7)

\begin{tabular}{|c|c|c|}
\hline Dependent variable & $\begin{array}{c}\text { Comparison group variable } \\
\text { mean (s.d.) }\end{array}$ & $\begin{array}{l}\text { Coefficient estimate (s.e.) on } \\
\text { programme indicator }\end{array}$ \\
\hline \multicolumn{3}{|l|}{ Panel A: Sample attrition } \\
\hline Surveyed in follow-up round (2005-7) & $0.816(0.388)$ & $-0.007(0.035)$ \\
\hline \multicolumn{3}{|l|}{ Panel B: Test scores } \\
\hline Arithmetic test (normalized) & $0.00(1.00)$ & $0.135(0.102)$ \\
\hline English vocabulary test (normalized) & $0.00(1.00)$ & $0.162 *(0.092)$ \\
\hline Raven's matrix test (normalized) & $0.00(1.00)$ & $0.182 * *(0.075)$ \\
\hline Reading test (normalized) & $0.00(1.00)$ & $0.124 *(0.071)$ \\
\hline Swahili vocabulary test (normalized) & $0.00(1.00)$ & $0.218 * *(0.088)$ \\
\hline Test score mean effect & $0.00(1.00)$ & $0.208 * *(0.092)$ \\
\hline Test score mean effect, among those with baseline scores $<+2$ s.d. & $0.06(0.96)$ & $0.145^{*}(0.082)$ \\
\hline Test score mean effect, among schools with $\leq 5$ predicted GSP winners & $-0.06(1.01)$ & $0.177 * *(0.081)$ \\
\hline \multicolumn{3}{|l|}{ Panel C: Schooling outcomes } \\
\hline Attended at least some secondary school $(0-1)$ & $0.30(0.46)$ & $0.087 * *(0.041)$ \\
\hline Still in school, at time of survey $(0-1)$ & $0.52(0.50)$ & $0.079 *(0.044)$ \\
\hline Grades of school completed & $7.8(1.2)$ & $0.088(0.103)$ \\
\hline
\end{tabular}

Notes

Each row is from a separate OLS regression. Significant at $90 \%(*), 95 \%(* *), 99 \%(* * *)$ confidence.

In panels B and C the outcome variable is regressed on the GSP (treatment) indicator, an indicator for student cohort, student age at time of the survey, educational attainment of each parent, and timing of the follow-up survey (coefficient estimates not shown). There are no additional regression controls in panel A. Standard errors are clustered by school. The sample size is 1387 observations in panels B and C. Details on the mean effect analysis are in the text. The test score mean effect in panel B includes the arithmetic, English, Raven's matrix, reading and Swahili test results. 
Table 3

\section{Autonomy in Household Outcomes in Follow-up survey (2005-7)}

\begin{tabular}{|c|c|c|}
\hline Dependent variable & $\begin{array}{l}\text { Comparison group } \\
\text { variable mean (s.d.) }\end{array}$ & $\begin{array}{l}\text { Coefficient estimate (s.e.) } \\
\text { on programme indicator }\end{array}$ \\
\hline $\begin{array}{l}\text { 'Women have always been subject to traditional laws and customs and should remain } \\
\text { so.' ( } 0 \text { to } 1) \text { (vs. 'Women should have equal rights and receive the same treatment as } \\
\text { men do.') [AFB] }\end{array}$ & $0.17(0.31)$ & $-0.009(0.022)$ \\
\hline $\begin{array}{l}\text { 'Men can beat their wives and children if they misbehave.' ( } 0 \text { to } 1) \text { (vs. 'No one has } \\
\text { the right to use physical violence against anyone else.') [AFB] }\end{array}$ & $0.25(0.38)$ & $-0.068 * * *(0.024)$ \\
\hline Ever married $(0-1)$ & $0.21(0.41)$ & $-0.018(0.034)$ \\
\hline Ever married, with family involvement in spouse choice $(0-1)$ & $0.042(0.201)$ & $-0.024 *(0.013)$ \\
\hline Ever married, without family involvement in spouse choice (0-1) & $0.165(0.371)$ & $0.005(0.031)$ \\
\hline Total fertility & $0.400(0.764)$ & $-0.030(0.065)$ \\
\hline Lack of autonomy mean effect & $0.00(1.00)$ & $-0.181 * *(0.077)$ \\
\hline
\end{tabular}

Notes

Each row is from a separate OLS regression. Significant at $90 \%(*), 95 \%(* *), 99 \%(* * *)$ confidence.

The outcome variable is regressed on the GSP (treatment) indicator, an indicator for student cohort, student age at time of the survey, educational attainment of each parent, and timing of the follow-up survey (coefficient estimates not shown). Standard errors are clustered by school. The sample size is 1387. Details on the mean effect analysis are in the text. The autonomy mean effect includes the two attitude questions and the 'Ever married, with family involvement in spouse choice' variables. AFB indicates a question from the Afrobarometer Survey. 
Table 4

Attitudes with Respect to Ethnicity, Religion and Democracy in Follow-up survey (2005-7)

\begin{tabular}{|c|c|c|}
\hline Dependent variable & $\begin{array}{l}\text { Comparison group } \\
\text { variable mean (s.d.) }\end{array}$ & $\begin{array}{l}\text { Coefficient estimate } \\
\text { (s.e.) on programme } \\
\text { indicator }\end{array}$ \\
\hline \multicolumn{3}{|l|}{ Panel A: Ethnic and religious attitudes } \\
\hline Ethnic identity is not 'very important' to respondent $(0-1)$ & $0.110(0.313)$ & $-0.033(0.020)$ \\
\hline $\begin{array}{l}\text { Ethnic identity is not 'very important' to respondent (0-1), among those surveyed in } \\
2005 \text { and } 2006\end{array}$ & $0.126(0.332)$ & $-0.042 *(0.021)$ \\
\hline Migrated out of Busia and Teso districts & $0.257(0.437)$ & $0.006(0.036)$ \\
\hline Religious identity is not 'very important' to respondent (0-1) & $0.014(0.116)$ & $0.005(0.006)$ \\
\hline Member of a prayer group $(0-1)$ & $0.371(0.483)$ & $0.018(0.034)$ \\
\hline \multicolumn{3}{|l|}{ Panel B: Democratic attitudes } \\
\hline $\begin{array}{l}\text { Agree with: 'We should choose our leaders in this country through regular, open and } \\
\text { honest elections.' ( } 0 \text { to } 1)\end{array}$ & $0.93(0.19)$ & $0.001(0.014)$ \\
\hline $\begin{array}{l}\text { Agree with: 'Democracy is preferable to any other kind of government' (0-1) AFB, } \\
\text { WVS] }\end{array}$ & $0.69(0.46)$ & $-0.005(0.035)$ \\
\hline $\begin{array}{l}\text { Disagree with: 'Only those who are sufficiently well educated should be allowed to } \\
\text { choose our leaders.' (0 to 1) [AFB] }\end{array}$ & $0.73(0.38)$ & $-0.022(0.030)$ \\
\hline $\begin{array}{l}\text { Disagree with: 'Only one political party should be allowed to stand for election and } \\
\text { hold office.' ( } 0 \text { to } 1) \text { [AFB] }\end{array}$ & $0.35(0.40)$ & $0.032(0.029)$ \\
\hline Disagree with: 'All decisions should be made by a council of elders.' ( 0 to 1$)$ [AFB] & $0.27(0.36)$ & $0.023(0.026)$ \\
\hline Disagree with: 'The military should come in to govern the country.' ( 0 to 1$)$ [AFB] & $0.61(0.41)$ & $0.002(0.033)$ \\
\hline $\begin{array}{l}\text { Disagree with: 'Elections and the Parliament should be abolished so that the president } \\
\text { can decide everything.' ( } 0 \text { to } 1) \text { [AFB] }\end{array}$ & $0.64(0.41)$ & $-0.006(0.032)$ \\
\hline Democratic attitudes mean effect & $0.00(1.00)$ & $0.023(0.098)$ \\
\hline
\end{tabular}

Notes

Each row is from a separate OLS regression. Significant at $90 \%(*), 95 \%(* *), 99 \%(* * *)$ confidence.

The outcome variable is regressed on the GSP (treatment) indicator, an indicator for student cohort, student age at time of the survey, educational attainment of each parent, and timing of the follow-up survey (coefficient estimates not shown). Standard errors are clustered by school. The sample size is 1387, except in the restricted sample for ethnic identity, where only those interviewed in 2005 and 2006 are included, in which case the sample size is 1346. Details on the mean effect analysis are in the text. The mean effect at the bottom of panel B includes all variables in that panel. AFB indicates a question from the Afrobarometer Survey, and WVS indicates a question from the World Values Survey. 
Table 5

Media Consumption, Political Knowledge and Satisfaction with Authority in Follow-up survey (2005-7)

\begin{tabular}{|c|c|c|}
\hline Dependent variable & $\begin{array}{l}\text { Comparison group } \\
\text { variable mean (s.d.) }\end{array}$ & $\begin{array}{l}\text { Coefficient estimate (s.e.) on } \\
\text { programme indicator }\end{array}$ \\
\hline \multicolumn{3}{|l|}{ Panel A: Media consumption } \\
\hline Days listened to the radio in last week ( 0 to 7 ) & $3.59(2.87)$ & $-0.642 * * *(0.198)$ \\
\hline Days read a newspaper in last week ( 0 to 7 ) & $0.439(1.010)$ & $0.134 *(0.074)$ \\
\hline Has a favourite newspaper & $0.666(0.472)$ & $0.096 * *(0.037)$ \\
\hline Favourite newspaper is the Daily Nation & $0.305(0.461)$ & $0.105 * * *(0.035)$ \\
\hline \multicolumn{3}{|l|}{ Panel B: Political knowledge } \\
\hline Political knowledge mean effect & $0.00(1.00)$ & $0.203 * *(0.085)$ \\
\hline \multicolumn{3}{|l|}{ Panel C: Satisfaction with authority } \\
\hline $\begin{array}{l}\text { 'We should show more respect for authority.' ( } 0 \text { to } 1) \text { (vs. 'As citizens, we } \\
\text { should be more active in questioning the actions of our leaders.') [AFB] }\end{array}$ & $0.53(0.46)$ & $-0.076 * * *(0.026)$ \\
\hline Kenya's quality of government is better than two years ago (0-1) & $0.56(0.50)$ & $-0.054 *(0.031)$ \\
\hline Kenya's economy is better than two years ago (0-1) & $0.50(0.50)$ & $-0.058 *(0.033)$ \\
\hline Satisfaction with Kenyan democracy ( 0 to 1 ) [WVS] & $0.74(0.29)$ & $-0.048 * * *(0.017)$ \\
\hline Satisfaction with authority mean effect & $0.00(1.00)$ & $-0.239 * * *(0.061)$ \\
\hline Taking everything together, respondent is 'very happy' $(0-1)$ [WVS] & $0.65(0.48)$ & $-0.027(0.039)$ \\
\hline \multicolumn{3}{|l|}{ Notes } \\
\hline
\end{tabular}




\section{Table 6}

Perceived Political Efficacy, Participation in Politics and Civic Affairs, and Attitudes Towards Violence in Politics in Follow-up Survey (2005-7)

\begin{tabular}{|c|c|c|}
\hline Dependent variable & $\begin{array}{l}\text { Comparison group } \\
\text { variable mean (s.d.) }\end{array}$ & $\begin{array}{l}\text { Coefficient estimate } \\
\text { (s.e.) on programme } \\
\text { indicator }\end{array}$ \\
\hline \multicolumn{3}{|l|}{ Panel A: Perceived political efficacy } \\
\hline $\begin{array}{l}\text { Disagree with: 'Politics and government sometimes seem so complicated that you can't } \\
\text { really understand what's going on.' ( } 0 \text { to } 1) \text { [AFB] }\end{array}$ & $0.16(0.29)$ & $0.009(0.020)$ \\
\hline $\begin{array}{l}\text { Disagree with: 'This world is run by a few people in power, and there is not much that } \\
\text { someone like me can do about it.' ( } 0 \text { to } 1)\end{array}$ & $0.30(0.37)$ & $0.019(0.027)$ \\
\hline Perceived political efficacy mean effect & $0.00(1.00)$ & $0.055(0.066)$ \\
\hline \multicolumn{3}{|l|}{ Panel B: Participation in politics and civic affairs } \\
\hline Interested in public affairs (0-1) [AFB, WVS] & $0.26(0.44)$ & $-0.028(0.028)$ \\
\hline Respondent intends to vote in the next presidential election $(0-1)$ & $0.48(0.50)$ & $-0.025(0.045)$ \\
\hline Community group memberships & $1.41(1.39)$ & $0.059(0.105)$ \\
\hline Participation in politics and civic affairs mean effect & $0.00(1.00)$ & $-0.038(0.073)$ \\
\hline $\begin{array}{l}\text { 'Generally speaking, would you say that most people can be trusted or that you need to } \\
\text { be very careful in dealing with people?' }(0-1) \text { [WVS] }\end{array}$ & $0.187(0.390)$ & $-0.018(0.025)$ \\
\hline \multicolumn{3}{|l|}{ Panel C: Political violence } \\
\hline $\begin{array}{l}\text { Agree with 'It is sometimes necessary to use violence in support of a just cause.' }(0-1) \\
\text { (vs. 'The use of violence is never justified in politics.') [AFB] }\end{array}$ & $0.23(0.42)$ & $0.059 * *(0.029)$ \\
\hline $\begin{array}{l}\text { 'It is sometimes necessary to use violence in support of a just cause.' ( } 0 \text { to } 1) \text { (vs. 'The } \\
\text { use of violence is never justified in politics.') [AFB] }\end{array}$ & $0.25(0.39)$ & $0.040(0.028)$ \\
\hline
\end{tabular}

Notes

Each row is from a separate OLS regression. Significant at $90 \%(*), 95 \%(* *), 99 \%(* * *)$ confidence.

The outcome variable is regressed on the GSP (treatment) indicator, an indicator for student cohort, student age at time of the survey, educational attainment of each parent, and timing of the follow-up survey (coefficient estimates not shown). Standard errors are clustered by school. The sample size is 1387. Details on the mean effect analysis are in the text. The mean effect at the bottom of panel A includes all variables in that panel, and the mean effect in panel B includes all variables except for the trust question. The sample size for the 'intends to vote in the next presidential election' analysis falls to 963 because the question was asked only of those respondents old enough to vote in the next election. The types of community groups include: women's groups; farmer/agricultural groups; youth groups; water groups/well committees, credit, saving, or insurance groups; prayer or bible study groups; burial committees; school committees or clubs; sports teams; other community group. AFB indicates a question from the Afrobarometer Survey, and WVS indicates a question from the World Values Survey. 


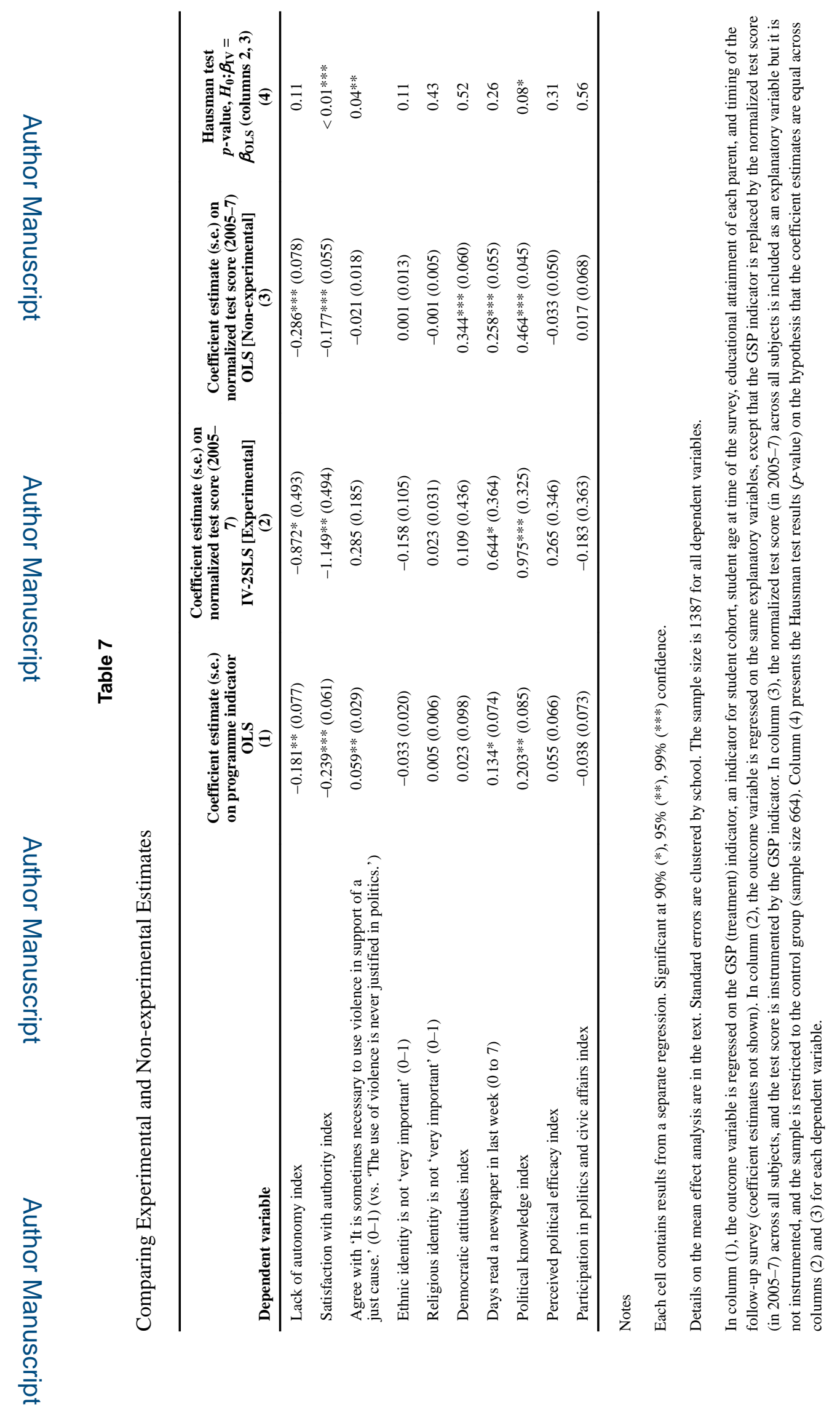

Economica. Author manuscript; available in PMC 2017 October 06. 